\title{
Partial HELLP syndrome: case report
}

\section{Sheetal Dagar*, Monika Gupta, Vrinda Shekhawat, Santosh Minhas}

\begin{abstract}
Department of Obstetrics and Gynecology, Maharishi Markandeshwar Medical College and Hospital, Solan, Himachal Pradesh, India
\end{abstract}

Received: 18 October 2021

Accepted: 10 November 2021

\author{
*Correspondence: \\ Dr. Sheetal Dagar, \\ E-mail: sheetaldagar7777777@gmail.com
}

Copyright: () the author(s), publisher and licensee Medip Academy. This is an open-access article distributed under the terms of the Creative Commons Attribution Non-Commercial License, which permits unrestricted non-commercial use, distribution, and reproduction in any medium, provided the original work is properly cited.

\begin{abstract}
HELLP syndrome is a complication in pregnancy clustered by haemolysis, elevated liver enzymes, and a low platelet count. It is seen as a serious complication of preeclampsia and eclampsia. Serious manifestations like haemorrhage, infarction, rupture and other hepatic manifestations are usually associated with it. In this case study, 29 years old primigravida is a booked case admitted in ward at 39 weeks 1 day with decreased fetal movement for 2 days. No history of pain abdomen, bleeding per vaginum, discharge per vaginum. Her blood pressure records at the time of admission was $110 / 72 \mathrm{mmHg}$ and she was normotensive throughout pregnancy. Urine routine examination was negative for urinary protein. However, blood tests showed platelet count of 66,1000/cumm, with ALT of $174 \mathrm{U} / \mathrm{L}$ and AST of 123 $\mathrm{U} / \mathrm{L}$ on peripheral blood film. RBC were predominantly normocytic, normochromic with few macrocytes. WBC has normal morphology. Platelets were reduced on smear. Giant platelets were seen. Ursodeoxycholic acid $300 \mathrm{mg} 12$ hourly were given to the patient and 3 doses of vitamin K I/M 24 hourly. She was delivered by cesarean section which was performed due to failure of progression of labor with a deflexed head. There was presence of retroplacental clot of $4 \times 3 \mathrm{~cm}$ indicating placental abruption, a complication of HELLP syndrome. From this we conclude that we should be careful in suspecting complications of full blown diseases even when the patients are asymptomatic but have atypical laboratory findings.
\end{abstract}

Keywords: Abruption, Low liver enzymes, Partial HELLP, Thrombocytopenia

\section{INTRODUCTION}

HELLP syndrome is a complication in pregnancy clustered by haemolysis with a microangiopathic blood smear, elevated liver enzymes, and a low platelet count. ${ }^{1}$ It is seen as a serious complication of preeclampsia and eclampsia. ${ }^{2}$ Serious manifestations like haemorrhage, infarction, rupture and other hepatic manifestations are usually associated with HELLP syndrome and severe preeclampsia. A mother with a previous history of HELLP or preeclampsia is at major risk for developing HELLP syndrome.

A variety of genetic variants plays a significant role in increasing risk of HELLP syndrome which have been reported in due course of research, but have no role in clinical management. There is a hypothesis that the complement cascade is a key mediator in systemic inflammatory disorder like severe preeclampsia/HELLP and it has been observed that women with complement regulatory protein mutations appear to be at increased risk of severe preeclampsia and HELLP syndrome. Fetal longchain 3-hydroxyacyl CoA dehydrogenase (LCHAD) deficiency appears to be related to the underlying etiology. ${ }^{3,4}$ Whereas, nulliparity is not a risk factor for HELLP syndrome in contrast to preeclampsia, as most of the affected patients are multiparous. ${ }^{5,6}$

\section{CASE REPORT}

In this case study, 29 years old primigravida is a booked case admitted in ward at 39 weeks 1 day with decreased 
fetal movement for 2 days. No History of pain abdomen, bleeding per vaginum, discharge per vaginum, burning micturition, easy fatigability, headache, blurring of vision, epigastric pain, decreased urine output. Ultrasound scans in the first and second trimester were corresponding to the period of gestation. Her routine antenatal investigations and the blood pressure recordings were normal throughout pregnancy. No maternal risk factors were found. Her past history and family history were insignificant.

Table 1: HELLP syndrome.

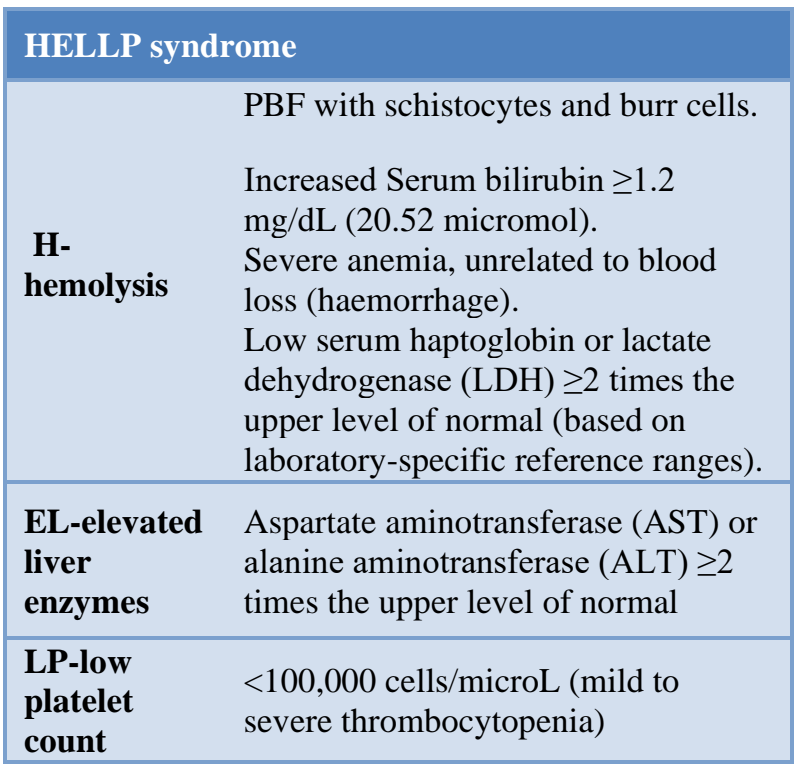

Table 2: Investigations.

\begin{tabular}{|c|c|c|}
\hline Investigations & On admission & $\begin{array}{l}\text { Day after } \\
\text { operation }\end{array}$ \\
\hline $\begin{array}{l}\text { Urine routine for } \\
\text { protein }\end{array}$ & Negative & Negative \\
\hline Platelet count & $66,1000 /$ cumm & $1,0,5000 / \mathrm{cumm}$ \\
\hline $\begin{array}{l}\text { Liver Function } \\
\text { Test }\end{array}$ & $\begin{array}{l}\text { ALT of } 174 \mathrm{U} / \mathrm{L} \\
\text { and AST of } 123 \\
\text { U/L } \\
\text { Bilirubin }(\mathrm{T}) \text { - } \\
0.20 \mathrm{mg} / \mathrm{dl} \\
\text { Bilirubin (D) - } \\
0.30 \mathrm{mg} / \mathrm{dl}\end{array}$ & $\begin{array}{l}\text { ALT of } 161 \\
\text { U/L and AST } \\
\text { of } 95 \mathrm{U} / \mathrm{L} \\
\text { Bilirubin }(\mathrm{T}) \text { - } \\
0.20 \mathrm{mg} / \mathrm{dl} \\
\text { Bilirubin (D) - } \\
0.30 \mathrm{mg} / \mathrm{dl}\end{array}$ \\
\hline $\begin{array}{l}\text { Peripheral blood } \\
\text { film }\end{array}$ & $\begin{array}{l}\text { RBC: } \\
\text { Predominantly } \\
\text { normocytic } \\
\text { normochromic } \\
\text { with few } \\
\text { macrocytes } \\
\text { WBC: Normal } \\
\text { morphology } \\
\text { Platelets: } \\
\text { Reduced on } \\
\text { smear, giant } \\
\text { platelets were } \\
\text { seen }\end{array}$ & - \\
\hline LDH & $201 \mathrm{IU} / 1$ & \\
\hline
\end{tabular}

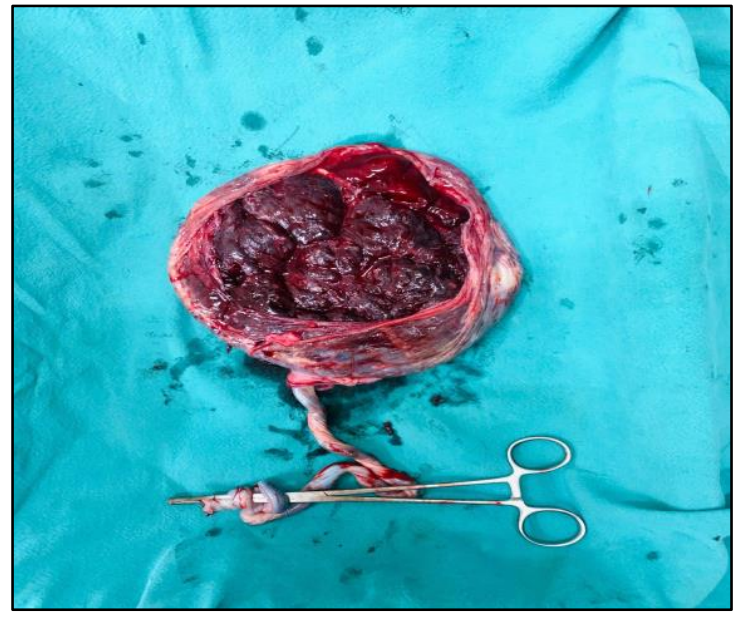

Figure 1: Retroplacental clot of size $5 \times 3 \mathrm{~cm}$ suggesting placental abruption.

Her blood pressure records at the time of admission was $110 / 72 \mathrm{mmHg}$. Urine routine examination was negative for urinary protein. However, blood tests showed platelet count of 66,1000/cumm, with ALT of $174 \mathrm{U} / \mathrm{L}$ and AST of $123 \mathrm{U} / \mathrm{L}$ on peripheral blood film, RBC were predominantly normocytic normochromic with few macrocytes, WBC had normal morphology, platelets were reduced on smear, giant platelets were seen. Repeat blood tests showed a decrease in platelet count of 6o, 1000/cumm.

Ursodeoxycholic acid $300 \mathrm{mg} 12$ hourly were given to the patient and 3 doses of vitamin K I/M 24 hourly. After three doses of dinoprostone gel $0.5 \mathrm{mg}$ instilled through intracervical route, patient went into labour and delivery by cesarean section was performed due to failure of progression of labor with deflexed head, baby delivered as vertex presentation with clear liquor with birth weight 3.5 $\mathrm{kg}$ and Apgar score of 9-10 and 9-10 (1-5 min), respectively. There was presence of retroplacental clot of $5 \times 3 \mathrm{~cm}$ indicating placental abruption, a complication of HELLP syndrome but the patient's vitals were stable throughout the operation, otherwise placenta and cord both were normal. 2 units FFPs given intraoperatively.

Postoperative period remained uneventful, there was no postpartum haemorrhage or puerperal sepsis. On postoperative day 1 patient's blood samples showed platelet count of $105 \times 1000 /$ cumm, with ALT of $161 \mathrm{U} / \mathrm{L}$ and AST of $95 \mathrm{U} / \mathrm{L}$. Patient was discharged on post op day 5 in satisfactory condition with the baby and the baby remained motherside throughout this time.

\section{DISCUSSION}

As our patient was asymptomatic but had atypical features of HELLP syndrome at the time of delivery at term, with typical absence of raised blood pressure and Hemolysis. Hemolysis is otherwise an essential part of the HELLP syndrome ("H"-hemolysis). Whereas, raised liver enzymes, resulting from the liver involvement ("EL"- 
elevated liver enzymes) 3-4 times higher than upper limit, in combination with thrombocytopenia ("LP"- low platelet).

HELLP syndrome is a serious condition that may result in a series of adverse maternal and neonatal consequences. ${ }^{7,8}$ Similar cases have been reported showing atypical cases of HELLP syndrome. Up till now, HELLP syndrome is considered as one of the most serious forms of preeclampsia, not as a separate disorder.

\section{CONCLUSION}

We reached the diagnosis of partial HELLP on the basis of the laboratory findings, despite a normal blood pressure and lack of hemolysis with an absence of typical symptoms but presence of concealed retroplacental clot indicating placental abruption, a complication of HELLP syndrome. From this we conclude that we should be careful in suspecting complications of full blown diseases even when the patients are asymptomatic but have atypical laboratory findings.

Funding: No funding sources Conflict of interest: None declared

Ethical approval: Not required

\section{REFERENCES}

1. Stone JH. HELLP syndrome: hemolysis, elevated liver enzymes, and low platelets. JAMA. 1998;280:559.
2. Sibai BM. Diagnosis, controversies, and management of the syndrome of hemolysis, elevated liver enzymes, and low platelet count. Obstet Gynecol. 2004;103:981-91.

3. Yang Z, Yamada J, Zhao Y. Prospective screening for pediatric mitochondrial trifunctional protein defects in pregnancies complicated by liver disease. JAMA. 2002;288:2163.

4. Yang Z, Zhao Y, Bennett MJ. Fetal genotypes and pregnancy outcomes in 35 families with mitochondrial trifunctional protein mutations. Am J Obstet Gynecol. 2002;187:715.

5. Lachmeijer AM, Arngrı msson R, Bastiaans EJ. A genome-wide scan for preeclampsia in the Netherlands. Eur J Hum Genet. 2001;9:758.

6. Abildgaard U, Heimdal K. Pathogenesis of the syndrome of hemolysis, elevated liver enzymes, and low platelet count(HELLP): a review. Eur J Obstet Gynecol Reprod Biol. 2013;166:17.

7. Bhattacharya S, Campbell DM. The incidence of severe complications of preeclampsia. Hypertens Pregnancy. 2005;24:181-90.

8. Barton JR, Sibai BM. Diagnosis and management of hemolysis, elevated liver enzymes, and low platelets syndrome. Clin Perinatol. 2004;31:807-33.

Cite this article as: Dagar S, Gupta M, Shekhawat V, Minhas S. Partial HELLP syndrome: case report. Int J Reprod Contracept Obstet Gynecol 2021;10:4570-2. 